\title{
A MODEL OF EQUILIBRIUM CONDITIONS OF ROOF ROCK MASS GIVING CONSIDERATION TO THE YIELDING CAPACITY OF POWERED SUPPORTS
}

\section{MODEL RÓWNOWAGI STROPOWEJ BRYLY GÓROTWORU UWZGLĘDNIAJĄCY PODATNOŚĆ ŚCIANOWEJ SEKCJI OBUDOWY ZMECHANIZOWANEJ}

\begin{abstract}
The work presents the model of interactions between the powered roof support units and the rock mass, while giving consideration to the yielding capacity of the supports - a value used for the analysis of equilibrium conditions of roof rock mass strata in geological and mining conditions of a given longwall. In the model, the roof rock mass is kept in equilibrium by: support units, the seam, goafs, and caving rocks (Fig. 1).

In the assumed model of external load on the powered roof support units it is a new development - in relation to the model applied in selection of supports based on the allowable deflection of roof theory that the load bearing capacity is dependent on the increment of the inclination of the roof rock mass and on the properties of the working medium, while giving consideration to the air pockets in the hydraulic systems, the load of the caving rocks on the caving shield, introducing the $R_{A}$ support value of the roof rock mass by the coal seam as a closed-form expression and while giving consideration to the additional support provided by the rocks of the goaf as a horizontal component $R_{01 H}$ of the goaf reaction.

To determine the roof maintenance conditions it is necessary to know the characteristics linking the yielding capacity of the support units with the heading convergence, which may be measured as the inclination angle of the roof rock mass. In worldwide mining, Ground Reaction Curves are used, which allow to determine the required yielding capacity of support units based on the relation between the load exerted on the unit and the convergence of the heading ensuring the equilibrium of the roof rock mass. (Figs. 4 and 8).

The equilibrium of the roof rock mass in given conditions is determined at the displacement of the rock mass by the $\alpha$ angle, which impacts the following values: yielding capacity of units $F_{N}$, vertical component of goaf reaction $R_{01 V}$ and the horizontal component of goaf reaction $R_{01 H}$.

In the model of load on the support units giving consideration to the load of the caving shield, a model of support unit was used that allows for unequivocal determination of the yielding capacity of the support with consideration given to the height of the unit in use and the change in the inclination of the canopy resulting from the displacement of the roof of the longwall.

The yielding capacity of the support unit and its point of application on the canopy was determined using the method of units which allows for the internal forces to be manifested.

The weight of the rock mass depends on the geological and mining conditions, for which the shape and dimensions of the rock mass affecting the support unit are determined.
\end{abstract}

* SILESIAN UNIVERSity OF TECHNOLOGY, FACULTY OF MINING AND GEOLOGY, DEPARTMENT OF MINING MECHANIZATION AND ROBOTISATION, AKADEMICKA 2, 44-100 GLIWICE, POLAND

\# Corresponding author: arkadiusz.pawlikowski@polsl.pl 
The resultant force of the pressure of gob on the gob shield was calculated by assuming that the load may be understood as a pressure of ground on a wall. This required the specification of the volume of the fallen rocks that affect the unit of powered roof supports (Fig. 2).

To determine the support of the roof rock mass by the coal seam, experience of the Australian mining industry was used. Experiments regarding the strength properties of coal have exhibited that vertical deformation, at which the highest seam reaction occurs while supporting the roof rock mass, amounts to $0.5 \%$ of the longwall's height. The measure of the width of the contact area between the rock mass and the seam is the width of the additional uncovering of the face roof due to spalling of seam topcorners $d_{a}$ (Fig. 2). With the above parameters and the value of the modulus of elasticity of coal in mind, the value of the seam's reaction may be estimated using the dependence (2).

The vertical component of the goafs' reaction may be determined based on the strength characteristics of the fallen roof, the contact area of the rock mass with the fallen roof and the mean strain of the fallen roof at the area of contact.

In the work by Pawlikowski (2014), a research procedure was proposed which encompasses model tests and exploitation tests of the loads exerted on the support units, aimed at the determination of the vertical component of the goaf reaction (Fig. 5). Based on duty cycles of powered roof support units, a mean value of the indicator of contact stiffness between the roof rock mass and the rocks constituting the caving is determined, assuming the linear dependence between the horizontal reaction and the heading convergence. The parameter allows for the determination of the horizontal component of the goafs' reaction in the external loading model of support units and allows for the determination of the required yielding capacity of supports, required to ensure the equilibrium of the roof rock mass.

The experimentally verified model of the external loading of the units was used to conduct simulations of interactions between the KOPEX-095/17-POz support unit and the rock mass in a face characterized by the height of $1.6 \mathrm{~m}$. Based on the data obtained in experiment, the variability of the yielding capacity of the support units was analyzed. A yielding capacity inclination angle of the units was determined for the registered curves (Figs. 6 and 7).

At the same time, the presentation of the lines corresponding to the required yielding capacity of units and characterizing the deformability of the support units, allows for the prediction of the yielding capacity of the powered supports and the convergence of the heading in the conditions of a given face (Fig. 9).

Keywords: powered roof support unit, deformability, yielding capacity, interaction with rock mass.

W pracy przedstawiono model interakcji sekcji obudowy zmechanizowanej z górotworem uwzgledniający podatność sekcji obudowy, który służy do analizy warunków równowagi stropowej bryły górotworu w warunkach geologiczno-górniczych określonej ściany. W modelu tym stropowa bryła górotworu utrzymywana jest w równowadze poprzez podparcie przez: sekcję obudowy, pokład, zroby i skały zawału uporządkowanego (Rys. 1).

W przyjętym modelu obciążenia zewnętrznego sekcji obudowy zmechanizowanej w stosunku do modelu stosowanego w metodzie doboru sekcji obudowy, opartej o teorię dopuszczalnego ugięcia stropu istotne novum stanowi uzależnienie podporności sekcji od przyrostu kąta nachylenia stropowej bryły górotworu i właściwości medium roboczego z uwzględnieniem zapowietrzenia układu hydraulicznego, uwzględnienie obciążenia osłony odzawałowej gruzowiskiem, wprowadzenie w postaci jawnej podparcia stropowej bryły górotworu przez pokład węgla $R_{A}$ oraz uwzględnienie dodatkowego podparcia przez skały tworzące zawał uporządkowany w postaci składowej poziomej reakcji zrobów $R_{01 H}$.

Dla ustalenia warunków utrzymania stropu niezbędna jest znajomość charakterystyki wiążącej podporność sekcji obudowy z konwergencją wyrobiska, której miarą może być kąt nachylenia stropowej bryły górotworu. W górnictwie światowym stosuje się krzywe reakcji górotworu GRC (Ground Response Curves), które pozwalają na wyznaczanie wymaganej podporności sekcji obudowy na podstawie relacji obciążenia sekcji i konwergencji wyrobiska zapewniającej równowagę stropowej bryły górotworu (Rys. 4 i 8).

Stan równowagi stropowej bryły górotworu w danych warunkach ustala się przy przemieszczeniu stropowej bryły górotworu o kąt $\alpha$, który wpływa na wartość: podporności sekcji $F_{N}$, składowej pionowej reakcji zrobów $R_{01 V}$ i składowej poziomej reakcji zrobów $R_{01 H}$. 
W modelu obciążenia sekcji obudowy z uwzględnieniem obciążenia osłony odzawałowej, wykorzystano model sekcji obudowy umożliwiający jednoznaczne wyznaczenie podporności sekcji obudowy z uwzględnieniem danej wysokości użytkowania sekcji i zmiany nachylenia stropnicy wynikającej z przemieszczania stropu wyrobiska ścianowego.

Podporność sekcji obudowy $F_{N}$ oraz jej punkt przyłożenia na stropnicy wyznaczono przy zastosowaniu metody przecięć, umożliwiającej uzewnętrznienie sił wewnętrznych.

Ciężar stropowej bryły górotworu zależy od warunków geologiczno-górniczych, dla których określa się kształt i wymiary bryły górotworu oddziałującej na sekcję obudowy.

Wypadkową nacisku zawału na osłonę odzawałową wyznaczono traktując jej obciążenie jak parcie gruntu na ścianę. Wymagało to określenia objętości rumowiska skalnego, które oddziałuje na sekcję obudowy zmechanizowanej (Rys. 2).

Do wyznaczenia podparcia stropowej bryły górotworu przez pokład węgla wykorzystano wiedzę wynikającą z doświadczeń górnictwa australijskiego. Badania eksperymentalne dotyczące właściwości wytrzymałościowych węgla wykazały, że odkształcenie pionowe, przy którym występuje największa reakcja pokładu przy podparciu stropowej bryły górotworu, stanowi 0,5\% wysokości ściany. Miarą szerokości kontaktu tej bryły z pokładem jest szerokość dodatkowego odsłonięcia pułapu wyrobiska w wyniku odspajania górnych naroży pokładu $d_{a}$ (Rys. 3). Znając powyższe parametry oraz wartość modułu sprężystości węgla można oszacować wartość reakcji pokładu z zależności (2).

Składową pionową reakcji zrobów $R_{01 V}$ można wyznaczyć na podstawie charakterystyki wytrzymałościowej rumowiska zawałowego, powierzchni styku bryły górotworu z tym rumowiskiem oraz średniego zgniotu rumowiska, występującego na tej powierzchni styku.

W pracy Pawlikowskiego (2014) zaproponowano procedurę badawczą obejmującą badania eksploatacyjne i modelowe obciążenia sekcji obudowy mającą na celu wyznaczenie składowej poziomej reakcji zrobów (Rys. 5). Na podstawie cykli pracy sekcji obudowy zmechanizowanej wyznacza się wartość średnią wskaźnika sztywności kontaktu stropowej bryły górotworu ze skałami tworzącymi zawał uporządkowany, przy założeniu liniowej zależności reakcji poziomej od konwergencji wyrobiska. Parametr ten umożliwia wyznaczenie składowej poziomej reakcji zrobów w modelu obciążenia zewnętrznego sekcji obudowy oraz pozwala na wyznaczenie wymaganej podporności sekcji obudowy niezbędnej dla zapewnienia równowagi stropowej bryły górotworu.

Zweryfikowany doświadczalnie model obciążenia zewnętrznego sekcji posłużył do przeprowadzenia symulacji interakcji sekcji obudowy KOPEX-095/17-POz z górotworem w ścianie o wysokości 1,6 m. W oparciu o uzyskane dane doświadczalne przeanalizowano zmienność podatności sekcji obudowy. Dla zarejestrowanych przebiegów rzeczywistych wyznaczono kąt nachylenia charakterystyki podpornościowej sekcji (Rys. 6 i 7).

Równoczesne przedstawienie prostych obrazujących wymaganą podporność sekcji i charakteryzujących podatność sekcji obudowy pozwala na predykcję podporności sekcji obudowy zmechanizowanej i konwergencji wyrobiska w warunkach danej ściany (Rys. 9).

Słowa kluczowe: sekcja obudowy zmechanizowanej, podatność, podporność, interakcja z górotworem

\section{Introduction}

A series of works regarding the problems of loading (Cheluszka \& Gawlik, 2016; Dolipski et al., 2014; Sobota, 2013) and safety of using longwall machines (Markowicz, 2010) are conducted at the Department of Mining Mechanization and Robotisation at the Faculty of Mining and Geology of the Silesian University of Technology. These problems are also covered by this paper, which regards the determination of the yielding capacities of powered roof supports, depending on the convergence of the heading in the mining and geological conditions of a given face.

Throughout the years, many methods of selection of the powered roof support units were applied: the Wilson's method - only encompassing the balance of forces, without consideration given to the convergence of the heading (Barczak \& Tadolini, 2008), Smart's method - giving consideration to the stiffness of individual supporting elements (Barczak \& Tadolini, 2008) and 
the method of the allowable deflection of roof applied in Poland - the method combines the previously mentioned methods and was developed based on empirical studies in the 1980s (Biliński, 2005; Biliński et al., 1997; Biliński, 1980). Unfortunately, the method does not take the progress in the form of the highly efficient faces into account. Moreover, the method of determining the yielding capacities of units does not provide for all structural features present in a shield support. The above methods used in the process of selecting the powered roof support units for a given geological and mining conditions, does not give consideration to the horizontal component of goafs' reaction in the area of contact between the roof rock mass and the rocks of the caving. Besides the above, the currently applied yielding capacity characteristics only represent the dependence between the initial yielding capacity and the operating yielding capacity of powered supports and the height of the face.

To determine the roof maintenance conditions it is necessary to know the characteristics linking the yielding capacity of the support units with the heading convergence, which may be measured as the inclination angle of the roof rock mass. Thus, in the recent years a concept of Ground Reaction Curves was developed, allowing for the determination of the required yielding capacity of the powered support unit based on the relation between the load exerted on the unit and the convergence of the heading, which ensures the equilibrium of the roof rock mass (Medhurst, 2005b; Barczak, 1993).

Moreover, in the support loading models applied up to now, the impact of the load exerted on the caving shield is not considered in the determination of the yielding capacity characteristics.

This work presents a model of interactions between the powered roof support unit and the environment while considering the matters referred to above.

\section{The model of external loading of the powered roof support unit with consideration given to the loading of the caving shield}

Forecasting the conditions of obtaining the equilibrium conditions of roof of rock mass requires the determination of the relation between the displacement of the roof rocks and the unit's yielding capacity resulting from its deformability. For that purpose a model of loading of a powered support unit in a longwall with caving was developed: the weight of the roof rock mass $Q_{1}$, the load exerted on the caving shield $Q$, the yielding capacity of the powered supports $F_{N}$, the reaction of the goafs in the form of the vertical component $R_{01 V}$ - resulting from the compressibility of goafs and the horizontal component $R_{01 H}$ - maintaining the basic roof in geometric continuity and the $R_{A}$ reaction - resulting from the support of the roof rock mass by the coal seam in the vicinity of the face (Fig. 1).

The following assumptions were made:

- the roof rock mass is maintained in equilibrium due to the support of the powered support unit, the seam, the goafs, and the rocks of the caving;

- the yielding capacity of the unit results from its characteristics dependent on the geometrical features of the unit, the operating height, the stiffness of the actuators of the supporting system and the convergence of the heading's floor and roof;

- the reaction of the seam is dependent on the deformation and the strength parameters of coal (Medhurst, 2005b); 


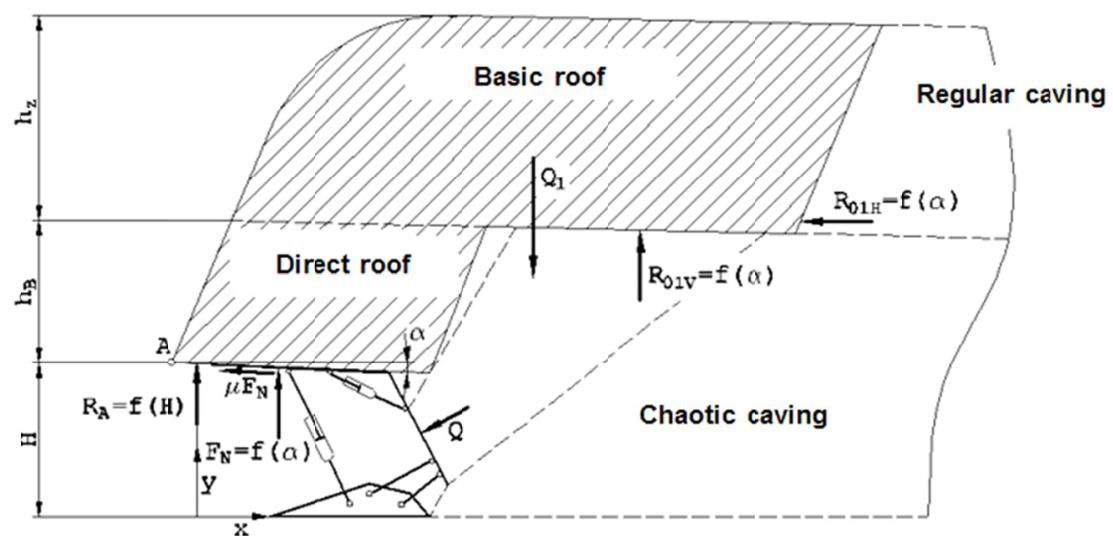

Fig. 1. Model of load exerted on a powered roof support in a longwall with caving (Pawlikowski, 2014)

- the vertical reaction of the goafs is the result of the influence of the basic roof and it depends on the displacement of the roof rock mass and the compressibility of the chaotic caving (Biliński, 1975);

- the horizontal reaction of goafs, resulting from the influence of the basic roof on the rocks of the regular caving, depends on the displacement of the roof rock mass;

- the external load exerted on the powered support unit is constituted by: the weight of the roof rock mass and the weight of the chaotic caving rocks;

- the dimensions and the weight of the roof rock mass depend on the height of the face and the type of the rocks constituting the direct and the basic roof (Biliński, 2005; Biliński, 1976);

- the resultant pressure of rocks constituting the chaotic caving on the caving shield depends on the volume of the fallen roof affecting the powered roof support unit.

As compared to the method of selecting the powered support units based on the allowable roof deflection theory (Biliński, 2005; Biliński et al.,1997), the assumed external loading model of a powered support is characterized by the following significant new developments:

- introduction if the dependence of the powered supports' yielding capacity from the increment of the inclination angle of the roof rock mass and the properties of the working medium while giving consideration to air pockets in the hydraulic system,

- giving consideration to the load exerted on the caving shield by the fallen roof,

- Introduction of the support of the roof rock mass by the coal seam as a closed-form expression $R_{A}$,

- giving consideration to an additional support of the roof rock mass by the rocks constituting the regular caving in the form of a horizontal component of the goaf reaction $R_{01 H}$.

The equilibrium of the roof rock mass in given conditions is determined at the displacement of the rock mass by the $\alpha$ angle, which impacts the following values: yielding capacity of units $F_{N}$, vertical component of goaf reaction $R_{01 V}$ and the horizontal component of goaf reaction $R_{01 H}$.

In the considerations, a flat model of loading of the powered support units was assumed. This is because the earlier analysis of static loading of the unit has indicated that the determination of the dimensional orientation of the vector line of the external load on the unit caused by the roof is burdened by much higher error as compared to the flat model (Markowicz et al., 2004). 


\subsection{Generalized model of the powered roof support unit}

In the model of loading of the powered support unit giving consideration to the load exerted on the caving shield, a generalized model of the powered support was used, which gives consideration to geometrical dimensions depending on the operational height of the unit and the inclination angle of the canopy as well as the fixed geometrical dimensions - independent of the height of the face (Jaszczuk \& Pawlikowski, 2006a; Jaszczuk et al., 2004a; Jaszczuk et al., 2004b). The model allows for an unequivocal determination of values describing the geometry of the powered support units based on a given operational height of the unit and the change in the inclination of the canopy, resulting from the displacement of the roof of a heading. In further considerations, a single-row shield roof support model was applied, as this solution is the one most often applied in the Polish and worldwide mining. The model was obtained by removing the second row of hydraulic props and the prop supporting the caving shield from the generalized model.

In the model, the yielding capacity of the support unit and its point of application on the canopy is determined using the method of units which allows for the internal forces to be manifested. Two units were made: through props, through the canopy's support and through the joint connecting the canopy with the caving shield as well as through the props and linkages of the lemniscate system.

The yielding capacity of the props and the canopy supports results from the kinematic excitation of the canopy movement related to the change in the inclination angle of the roof rock mass. The values were determined as the sum of the initial yielding capacity and the increment of force in the operating area of the actuators due to the increase of pressure in these areas at a given inclination angle of the immediate roof strata (Pawlikowski, 2014; Jaszczuk \& Pawlikowski, 2008).

While determining the increment of forces in the props and the canopy support, the following simplifying assumptions were made (Szweda, 2004):

- fixed volume of liquid in the props and canopy support working areas,

- elastic strain of upper props caused by external loading are negligibly small in relation to the radial deformation of the cylinder walls,

- the radial deformation of the cylinder caused by the increase of pressure in the working areas are fixed at the entire height of the column of liquid.

The $l_{c}$ liquid column in the working areas of the actuators of the support system is dependent on the height of the face, the setting of the canopy, and the design of the actuators. The change in the height of props and the canopy support results from the displacement of roof in relation to the floor of the heading.

Air pockets in the working medium are taken into account by means of the water-oil emulsion compressibility factor determined using the following dependence (Rajwa, 2004):

$$
e_{w}=\frac{1}{b_{c} \cdot B}\left[\mathrm{MPa}^{-1}\right]
$$

where:

$b_{c}$ - coefficient specifying the ratio of the elasticity modulus of the liquid with air pockets to the elasticity modulus of the liquid itself; in case of a hydraulic system of a powered roof support unit, the value of that coefficient is assumed to be in the $0.75 \div 0.80$ range (Rajwa, 2004; Stoiński, 2000),

$B$ - bulk modulus, for water it amounts to $2.3 \cdot 10^{3} \mathrm{MPa}$. 


\subsection{The load of the roof rock mass exerted on the powered roof support (Biliński, 2005; Kostyk, 2001)}

The weight of the rock mass depends on the geological and mining conditions, for which the shape and dimensions of the rock mass affecting the support unit are determined. The geometry of the rock mass are assumed for specified conditions of the roof, and so: the height of the immediate roof and the basic roof is related to the height of the face and the compressive strength of rocks and the self-supporting span is only dependent on the type of rocks occurring in the roof of the heading (Kidybiński, 1982; Biliński, 1976). The weight of the roof rock mass is also influenced by the location of formation of the relaxed rock mass in relation to the face. The location may be over the face of the longwall or may be protruded to the front of the face. This depends on the ratio of the rock mass pressure and the seam strength. The weight of the roof rock mass affecting the powered support unit is determined based on a unit of the mass with a width equal to the spacing of the units, calculated along the longwall and the length of the base equal to the span of the heading and height dependent on the compressive strength of the rocks constituting the roof of the heading.

\subsection{The load exerted on the caving shield resulting from the fallen roof}

The resultant force of the pressure of gob on the caving shield was calculated by assuming that the load may be understood as a pressure of ground on a wall (Jaszczuk \& Pawlikowski, 2006b). The determination of the load affecting the caving shield from the goaf side requires the determination of the volume of the fallen rocks which affects the powered support unit. The volume depends on the geological and mining conditions, for which a given shape of the rock mass, affecting the powered roof supports, is assumed (Fig. 1).

The volume of the rocks affecting the caving shield is separated by the face at the angle of repose $\varphi$, the slip plane with the inclination angle of $\vartheta$, the caving shield and the basic roof (Fig. 2). The load exerted on the caving shield at the side of goafs is determined based on the equilibrium

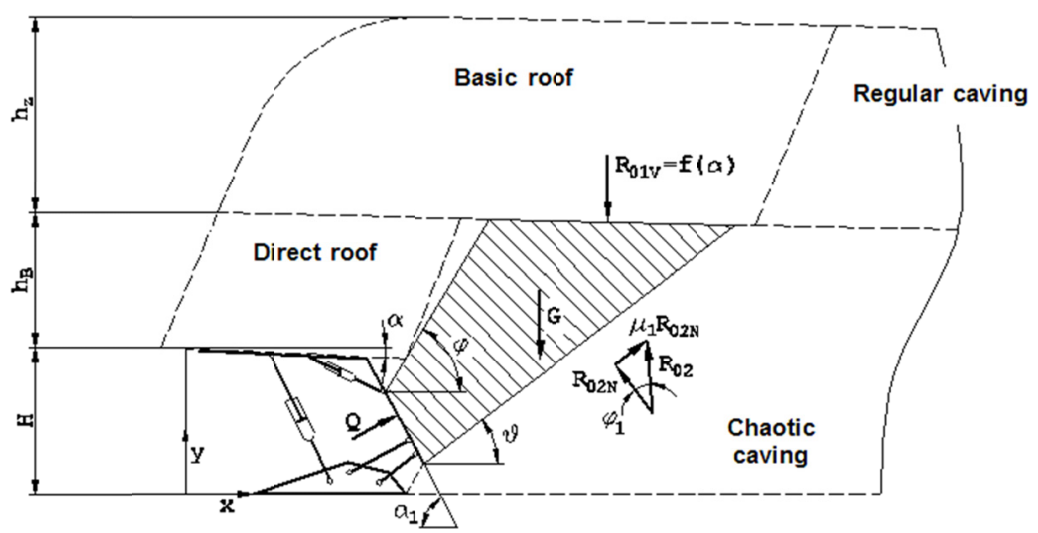

Fig. 2. A simplified diagram of the system of forces related to the load of the fallen roof material on the caving shield of the powered roof support (Pawlikowski, 2014) 
conditions: the canopy-caving shield assembly, the rock mass exerting the load on the support unit and the rocks exerting the load on the caving shield.

These conditions, along the conditions obtained using the method of units, allow for the analysis of the loading of the powered support units with the consideration given to the load exerted on the caving shield $Q$, and the determination of the yielding capacity of the units, depending on the type of the roof rocks, the inclination angle of the immediate roof, the face height $H$, the initial yielding capacity and the level of airlocking of the working medium.

\subsection{The reaction of the seam and goafs}

One of the significant, yet often neglected elements maintaining the equilibrium of the roof rock mass is the coal seam. To determine the value of the support of the roof rock mass by the coal seam, the knowledge resulting from the experiences of the Australian mining was used (Medhurst \& Brown, 1998). Experiments concerning the strength properties of coal have indicated that at a relative vertical deformation exceeding $0.5 \%$, a deformation of the uncovered surface of the seam (face of a longwall) occurs. Further deformation of coal due to the pressure of the roof rock mass causes the spalling of the topcorners of the seam.

The value of the $E_{w}$ elasticity modules of coal in Polish Hard Coal Basins is within the range of $1.2 \div 6.5 \mathrm{GPa}$, while the mean value is $3.5 \mathrm{GPa}$ (Kidybiński, 1982). Studies of coal in Australia have exhibited that the elasticity modulus of the coal deposits in that area varies in the range from $2 \mathrm{GPa}$ in case of easily mineable coal, up to $4 \mathrm{GPa}$ in case of coal that is difficult to mine (Medhurst, 2005b).

Considering the fact that the vertical deformation $\Delta H$ at which the highest reaction of the seam supporting the roof rock mass occurs, constitutes $0.5 \%$ of the face height and the measure of the contact of that rock mass with the seam is the width of the additional uncovering of the face roof due to spalling of the seam topcorners $d_{a}$ (Fig. 3), the value of that reaction may be estimated based on the above parameters using the following dependence:

$$
R_{A}=E_{w} \cdot \frac{\Delta H}{H} \cdot d_{a} \cdot t_{s e k}
$$

The vertical component of the goafs' reaction $R_{01 V}$ may be determined based on the strength characteristics of the fallen roof, the contact area of the rock mass with the fallen roof and the mean strain of the fallen roof at the area of contact (Biliński, 1975).

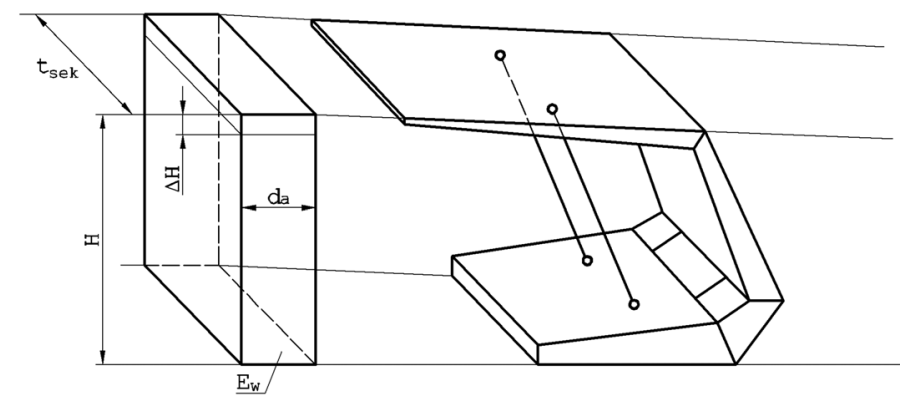

Fig. 3. Part of the compressed seam supporting the load resulting from the roof rock mass (Pawlikowski, 2014) 


\subsection{The horizontal component of the goaf reaction}

It may be inferred from the curves of the rock mass reaction (Barczak \& Tadolini, 2008; Medhurst, 2005b) that the horizontal component of the goaf reaction, constituting the support of the roof rock mass by means of the rocks of the regular caving and which maintains the rocks of the basic roof in geometric continuity, increases along the increase of the convergence of the heading up to reaching the convergence threshold, above which a higher yielding capacity of powered roof supports is required (C - Fig. 4).

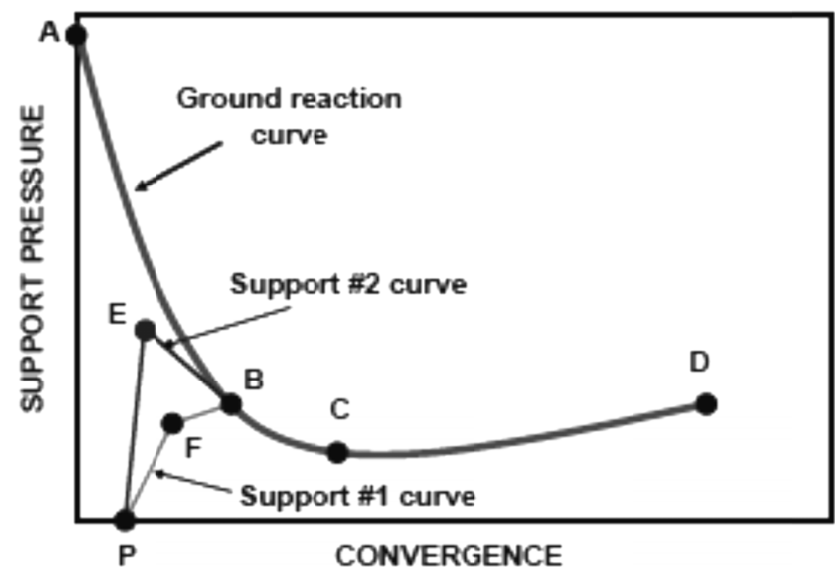

Fig. 4. A conceptual illustration of the interaction between the powered supports and the rock mass, using the rock mass reaction curve (Barczak \& Tadolini, 2008)

In the work by Pawlikowski (2014), a research procedure was proposed encompassing model tests and tests in exploitation of the loads exerted on the support units, aimed at the determination of the vertical component of the goaf reaction (Fig. 5).

The purpose of the in situ study is to obtain the data required for the analysis of the effect the convergence of the heading has on the yielding capacity of the powered support units. This requires the following curves to be obtained:

- pressure in the parts of props of the powered supports beneath pistons,

- the changes of positions of the canopy, sill piece and the caving shield due to the displacement of the roof rock mass.

Due to the continuous monitoring of the pressure in props and the inclination angle of the canopy, it is possible to determine the increment of the canopy inclination angle from the moment of expansion of the powered support unit, up to reaching the yield capacity in each cycle of loading the support units, related to the technological processes.

The achievement of measurement results should be preceded by an initial verification of the correctness of the registration of all curves. Measurement data disturbed by incorrect operation of sensors, interrupted data transmission or registration, is rejected. In the subsequent phase, the character of the curves should be analyzed and the curves which allow to achieve a homogeneous group in terms of the pressure increase curve in the part of the props beneath the pistons, should 
be qualified. In view of the analysis, it is important to achieve curves with diversified value of yielding capacity of the support unit before drawing off.

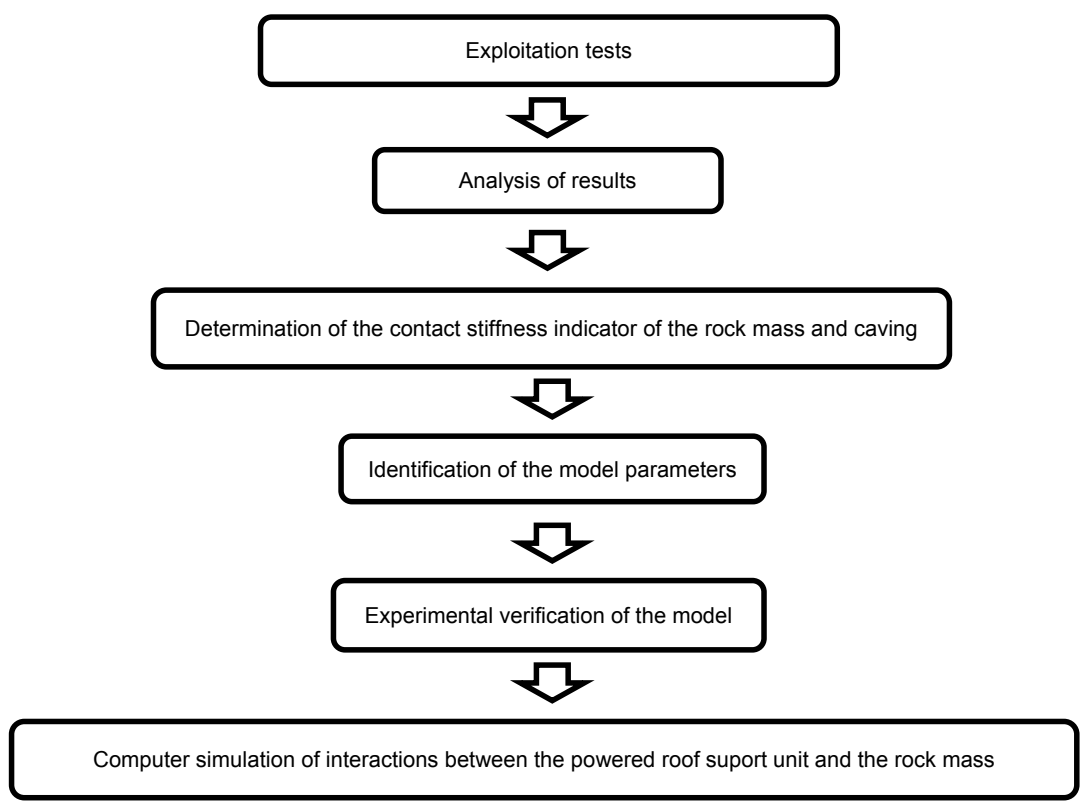

Fig. 5. The test procedure for determining the yield capacity of the support unit with consideration given to the horizontal component of the goaf reaction (Pawlikowski, 2014)

Based on the tests, data relating to extension (initial yielding capacity) and yielding capacities in each of the loading cycles of powered supports qualified for analysis is achieved. At the same time, the measurement of the unit's elements' position allows to determine the convergence of the heading during a cycle. Data prepared in such a manner are used for determining the horizontal component of the goaf's reaction using the model of the powered support unit's loading for each of the loading cycles in consideration. The calculations for the used support units are made in the geological and mining conditions of the longwall which served for obtaining the measured data.

For each analyzed duty cycle a value of the indicator of contact stiffness between the roof rock mass and the rocks constituting the regular caving is determined, assuming the linear dependence between the horizontal reaction and the heading convergence. After investigating the distribution of the coefficient, a mean value is assumed as the parameter which allows for the determination of the horizontal component of the goafs' reaction in the external loading model of support units and which allows for the determination of the required yielding capacity of supports, required to ensure the equilibrium of the roof rock mass. The dependence between the yielding capacity of the support unit achieved in that manner and the heading's convergence is an equivalent of the rock mass' reaction curve which corresponds to the supporting conditions of the roof rock mass due to the horizontal component of goaf reaction.

The empirical verification of the model included the comparison of the line obtained in the experiment for the working cycles that were not used in the determination of the contact stiffness 
coefficient between the roof rock mass and the rocks of the regular caving with the line obtained using the model and experimental data. Because the parametrization of the model concerns specified geological and mining conditions, the verification thereof may only be conducted based on data obtained for that same longwall.

The model of external loading of the unit, verified by means of an experiment, is used for conducting the simulation of the interaction between the powered support unit and the rock mass. As the first stage, the variability of deformability of the powered support unit should be analyzed based on the data obtained in experiment. An inclination angle of the yielding capacity characteristics of the unit, obtained by linking the point corresponding to the initial yielding capacity with the point corresponding to the yielding capacity, is determined for the actual curves. The line inclination angle depends on the structural features of the support units, the height of the face and the airlocking of the support system as well as the uncontrolled deformability resulting from the crushing of loose rocks under the sill pieces and/or the canopy of the support unit.

At the same time, the presentation of the lines corresponding to the required yielding capacity of units and characterizing the deformability of the support units, allows for the prediction of the yielding capacity of the powered supports and the convergence of the heading in the conditions of a given face.

\section{Simulation of interactions between the powered support unit and the roof rock mass (Pawlikowski, 2014)}

The experimentally verified model of external loading of the unit was used for conducting a simulation of interactions between the KOPEX-095/17-POz unit and the rock mass in case of a $1.6 \mathrm{~m}$ high face. For the purposes of the simulation, an analysis of the unit's deformability was conducted for the analyzed cycles of powered roof support loading.

The measure of deformability is the ratio of the increment of pressure during the loading cycle and the increment of the canopy inclination angle. The visual representation is constituted by the $\eta_{i}$ angle of inclination of lines presented in Figs. 6 and 7.

First, the inclination angles $\eta_{i}$ of the yielding capacity characteristics of the unit were determined based on the experimental data for the analyzed support unit loading cycles. In the conditions of a given face, the inclination angle of the lines may vary largely due to the presence of the uncontrolled deformability caused by factors such as: air pockets in the support system, crushing of the loose rocks beneath the sill pieces and/or on the canopy of the support unit. The geometrical properties of the unit and the range of operating heights of the unit in the conditions of a given face, vary insignificantly. This is why the properties do not have impact on the range of that angle. Critical inclination angles of the lines characterizing the deformability of the unit for the cycles in consideration are included between lines marked as bad.min ${ }_{\text {. }}$ and bad.max (Fig. 6).

Fig. 6 also presents the lines characterizing the deformability of the units, obtained as a result of a simulation conducted using the external loading model of a powered support, giving consideration to the load exerted on the caving shield. The simulation was conducted with consideration given to geometrical features of the powered support unit used at the face which served for obtaining the experimental data. Similar loading conditions, resulting from the weight of the roof rock mass, were assumed. In case of the specified initial yielding capacity of the 0.65 operating yielding capacity, the airlocking of the working medium was simulated by changing the $e_{w}$ compressibility factor. 


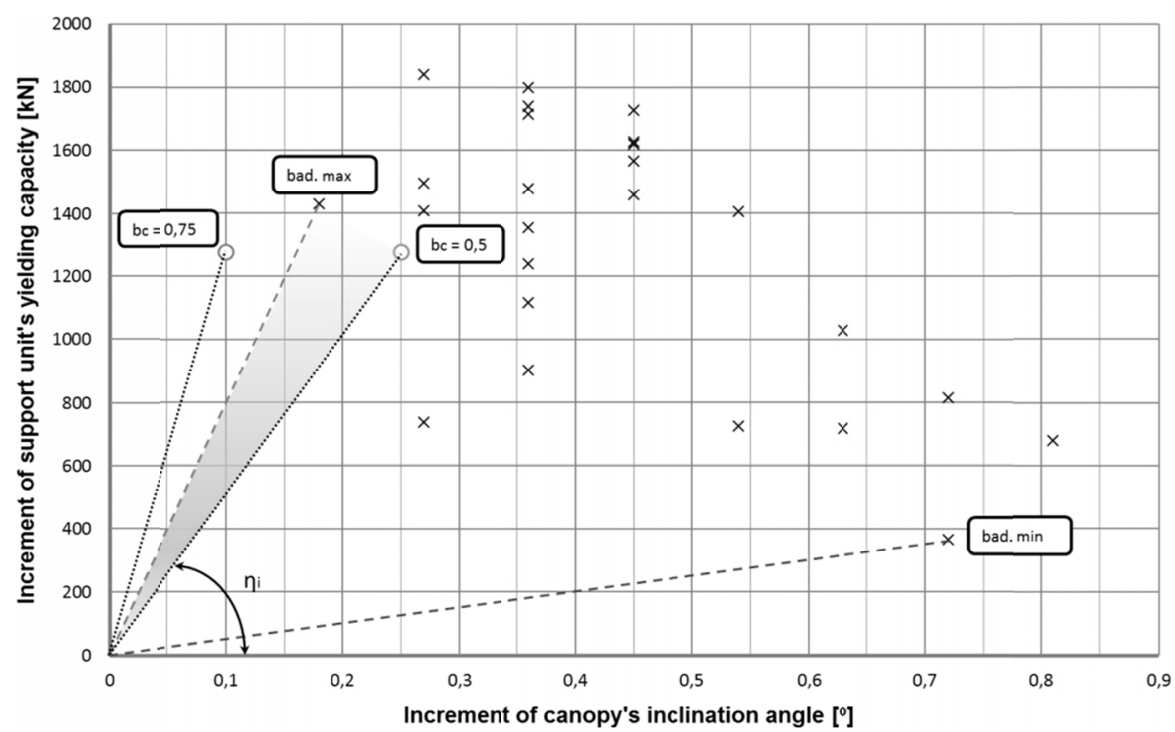

Fig. 6. Variability ranges of the support unit deformability depending on the convergence of the heading (Pawlikowski, 2014)

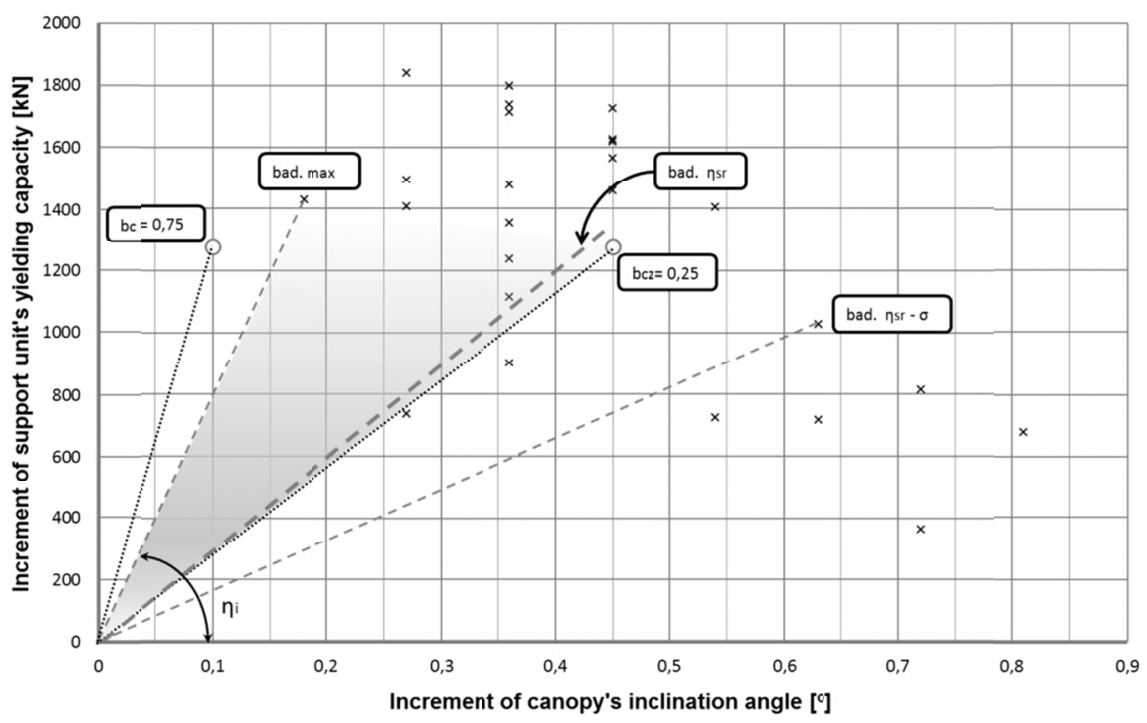

Fig. 7. Deformability of a powered support unit obtained taking the assumptions into account (Pawlikowski, 2014)

As it has been exhibited in the work (Rajwa, 2004), the value of the $b_{c}$ parameter from the range of $0.75 \div 0.80$, adopted so far for the double telescopic prop is too high and should fit in the range of $0.5 \div 0.6$. Due to the above, a theoretical value of the $b_{c}$ coefficient, amounting to 0.75 and the value of 0.5 was assumed to calculate the elasticity modulus $B_{c}(1)$. For the assumed 
values of the compressibility coefficient only giving consideration to the airlocking of the working medium, yielding capacity characteristics were determined. Fragments of the characteristics depicting the deformability of the unit depending on the convergence of the heading have been presented in Fig. 6.

The theoretical range of the inclination angle of lines depicting the deformability, resulting from airlocking (included between lines described as $=0.75$ and $b_{c}=0.5$ ), to a small extent overlaps the range of the angle obtained based on exploitation tests, included between the lines

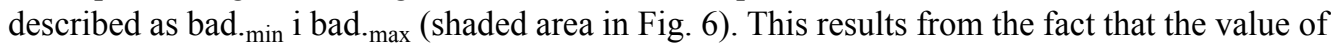
the $b_{c}$ coefficient in the range of $0.5 \div 0.75$, only gives consideration to the airlocking level of the working medium while not taking into account the uncontrolled deformability resulting e.g. from the compressibility of the rubble deposited on the canopy or under the sill piece. Due to the above, a substitute value of the $b_{c z}$ coefficient of 0.25 was assumed while taking the compressibility of the rubble into account, for which a line was made that depicts the deformability of the powered support unit (Fig. 7).

An occurrence frequency distribution of the inclination angles of lines characterizing the deformability of the powered support units was determined for the data obtained by means of tests and the mean value $\eta_{s r}$ of the inclination angle was found. As in the case of the $k_{R 01 H}$ contact stiffness coefficient, the variation range of that angle was determined to be in the range of $\eta_{s r}-\sigma$ and $\eta_{s r}+\sigma$. An area was established, in which $68.2 \%$ of the cases in concern occur in the range of $\pm \sigma$ from the mean value.

The applied limitation of the range of inclination angle of the lines characterizing the deformability of the support units for in situ tests using the $\eta_{s r}-\sigma$, line, results from the fact, that in case of the increment of the inclination angle of the roof rock mass higher than $0.45^{\circ}$, the convergence of the heading in the place of support of the canopy with the props exceeds the value of $20 \mathrm{~mm}$, at which - in line with the rock mass reaction curves - a higher yielding capacity of the supports is required due to the deteriorated roof support (Fig. 8).

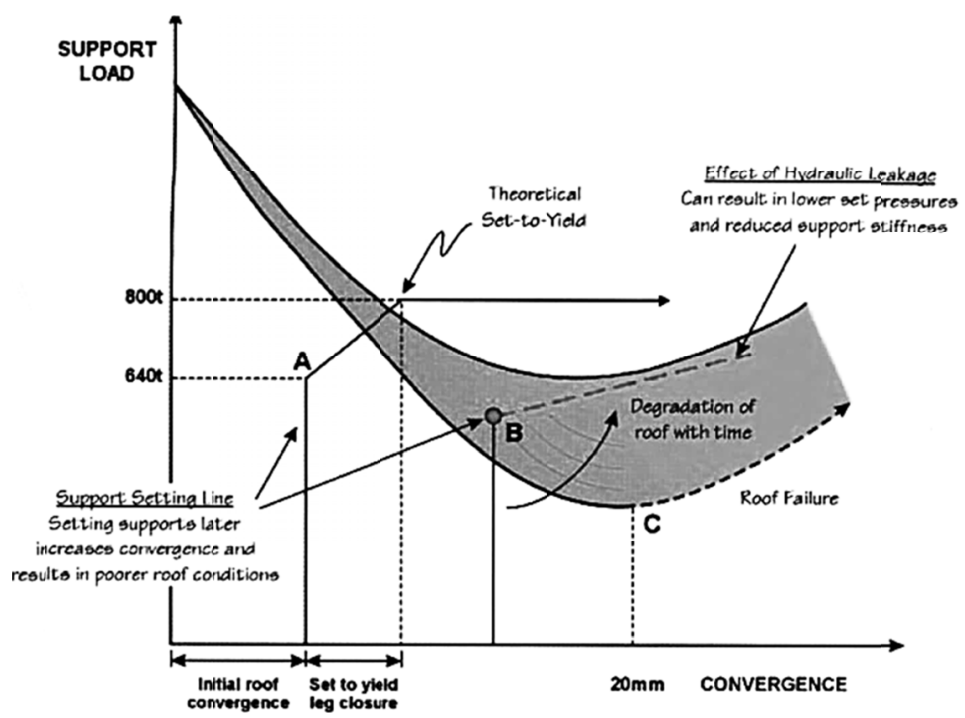

Fig. 8. Typical curves of the rock mass reaction (Jaszczuk, 2007; Medhurst, 2005a) 
The yielding capacity of the unit for the $\eta_{s r}-\sigma$ characteristic was obtained for the inclination angle increment of the roof rock mass of $0.62^{\circ}$, that is, for a convergence of the heading in the support point of the canopy using props of approximately $29 \mathrm{~mm}$.

The use of the substitute value of the $b_{c z}$ coefficient of 0.25 increased the common part of the theoretical inclination angle and the angle obtained in exploitation tests (included between the lines described as bad.max ${ }_{\text {max }}$ and $b_{c z}=0.25$ ) (Fig. 7).

The verification whether the yielding capacity of the unit obtained based on the data from tests falls within the operating range of the powered support described above, constituted the next stage of the experimental verification of the model. Plotting a single graph combining (Fig. 9.):

- lines depicting the required yielding capacity of the powered supports $F_{k y b a d}$, determined based on the proposed method for the mean value of contact stiffness indicator of rocks $\bar{k}_{R 01 H}$, in the point of application of the horizontal component of goaf reaction $R_{01 H}$ and the lines for the contact stiffness indicator of rocks $\bar{k}_{R 01 H} \pm 2 \sigma$ (dashed lines); (these lines are a fragment of the rock mass reaction curves corresponding to the reinforcement of the roof rock mass);

- lines characterizing the yielding capacity of the support units, obtained based on exploitation tests ( bad. $_{\eta s r-\sigma}$ ) and based on simulations for the coefficient value amounting to 0.75 (dotted lines); (lines obtained by connecting the point corresponding to the initial yielding capacity with the point corresponding to the yielding capacity of the unit for the loading of the unit in concern),

allowed to obtain graphical dependencies which made it possible to determine the range of yielding capacity of a powered support unit and the heading convergence in the conditions of a given face.

Double dotted lines stand for lines depicting the deformability of the support units obtained in the geological and mining conditions of the face under the analysis.

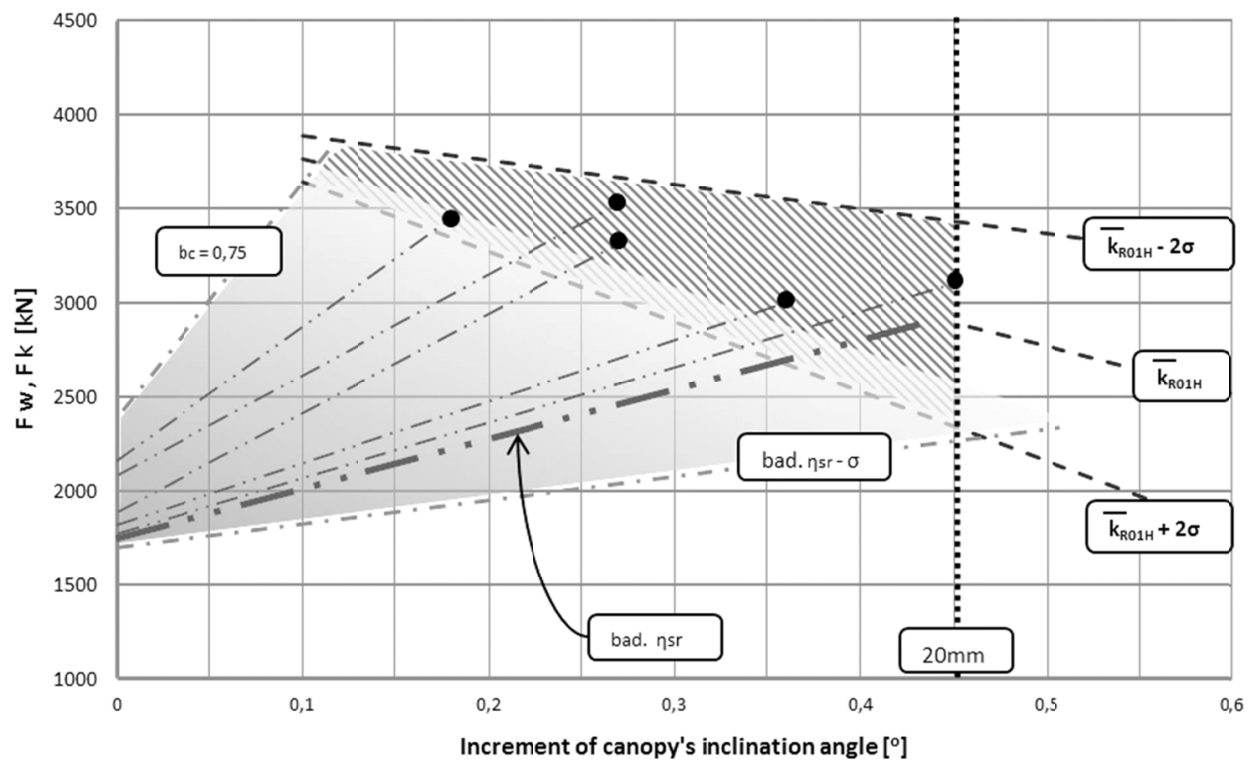

Fig. 9. The variability range of powered support's yielding capacity and the heading convergence in the conditions of the analysed face (Pawlikowski, 2014) 
Because all the points characterizing the yielding capacity of the powered support unit - in the conditions of the analyzed face - are within the range corresponding to the required yielding capacity, the analysis has exhibited that the proposed method of determining the equilibrium conditions of a roof of a rock mass in geological and mining conditions of a given face is a tool that allows for forecasting the heading convergence depending on the parameters of the roof support unit. Due to the above, it is possible to select support unit's parameters ensuring good roof supporting conditions.

\section{Summary}

The roof rock mass is maintained in equilibrium due to the interactions with the powered roof support units, the coal seam, the chaotic caving, and the regular caving. The yielding capacity of powered support unit, the vertical component of goaf reaction resulting from the compressibility of the rocks in the chaotic caving, and the vertical component of goaf reaction at the point of contact of the roof rock mass with the rocks of the regular caving, depend on the displacement of the roof rock mass.

In the models applied up to now, the horizontal component of goaf reaction was not considered and its determination allows to obtain a dependence which links the required yielding capacity of a powered support unit and the heading convergence measured as an inclination angle of the roof rock mass in the conditions of the heading covered by the measurements.

The developed model of powered roof support loading and the proposed procedure of conduct allow to determine the horizontal component of goaf reaction as a function of the heading convergence, based on the change of the parameters characterizing the geometry of the unit and the pressure in the actuators of the support system.

Based on the conducted simulations, it has been found that a decrease in the loading of the powered support unit occurs along the increase in heading convergence expressed as the increment of the inclination angle of the roof rock mass. Due to the above, a smaller yielding capacity of powered supports is required to achieve the planned roof subsidence. The decrease of the loading of the powered support results from the fact that in the initial phase of the roof subsidence, the horizontal reaction of the caving yielding capacity is high and maintains the geometric continuity of the basic roof and subsequently an increase of the vertical reaction of the goafs occurs due to the compressibility of the rocks constituting the chaotic caving.

The proposed method of analysis of equilibrium conditions of the roof rock mass in geological and mining conditions of a given face is a tool that allows for the determination of heading convergence depending on the parameters of the powered support. Due to the above, it is possible to select support unit's parameters ensuring good roof supporting conditions.

\section{References}

Barczak T.M., 1993. Design and Operation of Powered Supports for Longwall Mining. Engineering and Mining Journal 28-32.

Barczak T.M., Tadolini P.C., 2008. Longwall shield and standing gateroad support designs - is bigger better? Coal Age. 1-26. 
Biliński A., 2005. Metody doboru obudowy ścianowych wyrobisk wybierkowych i chodnikowych do warunków pola eksploatacyjnego. Prace naukowe - Monografie CMG KOMAG. Gliwice.

Biliński A.,1980. Empiryczna metoda doboru obudowy dla ścian zawałowych. Archiwum Górnictwa PAN 3, $321-344$.

Biliński A., 1976. Dobór obudowy wyrobisk ściany zawałowej. Bezpieczeństwo Pracy w Górnictwie 2(31), 1-7.

Biliński A., 1975. Kryteria utrzymania wyrobiska w ścianach zawałowych. Bezpieczeństwo Pracy w Górnictwie 1(26), 1-6.

Biliński A., Kostyk T., Prusek St., 1997. Zasady doboru obudowy zmechanizowanej dla wyrobisk ścianowych. Bezpieczeństwo Pracy i Ochrony Środowiska w Górnictwie, Miesięcznik WUG, Katowice 3(31), 14-23.

Cheluszka P., Gawlik J., 2015. Computer modelling of roadheader's body vibration generated by the working process. Vibration in Physical Systems, Vol. XXVII, 67-74.

Dolipski M., Remiorz E., Sobota P., 2014. Dynamics of Non-Uniformity Loads of AFC Drivep. Arch. Min. Sci. 59, 1, 155-168, Kraków.

Jaszczuk M., 2007: Ścianowe systemy mechanizacyjne. Wydawnictwo Naukowe Śląsk. Katowice.

Jaszczuk M., Pawlikowski A., 2008. Wptyw cech konstrukcyjnych stojaka na charakterystyke podatnościowa sekcji obudowy zmechanizowanej. Maszyny Górnicze 1, 7-11.

Jaszczuk M., Pawlikowski A., 2006a. Charakterystyki podpornościowe sekcji obudowy zmechanizowanej. Zeszyty Naukowe Politechniki Śląskiej, Seria: Górnictwo 274, 211-221.

Jaszczuk M., Pawlikowski A., 2006b. Oszacowanie wartości nacisku skał tworzacych zawał na osłonę odzawałowa sekcji obudowy zmechanizowanej. Zeszyty Naukowe Politechniki Śląskiej. Seria: Górnictwo 274, 223-231.

Jaszczuk M., Markowicz J., Pawlikowski A., 2004a. Wyznaczanie przebiegów czasowych składowych wektora obciążenia dynamicznego sekcji obudowy zmechanizowanej. KOMTECH 2004. Ustroń, 15-17 listopad. 113-120.

Jaszczuk M., Markowicz J., Pawlikowski A., 2004b. Modelowanie dynamicznego oddziaływania górotworu na sekcję obudowy zmechanizowanej z wykorzystaniem zasady kinetostatyki. Zeszyty Naukowe Politechniki Śląskiej, Seria: Górnictwo 260, 403-412.

Kidybiński A., 1982. Podstawy geotechniki kopalnianej. Wydawnictwo „Śląsk”. Katowice.

Kostyk T., 2001. Dobór ścianowej obudowy zmechanizowanej a bezpieczeństwo i efektywność produkcji. Maszyny Górnicze 85, 40-43.

Markowicz J., 2010. Analysis of Impact of Welded Joint Dameges and Corrosion in Powered Roof Support Components on Their Operational Safety. Arch. Min. Sci. 55, 4, 799-826, Kraków.

Markowicz J., Ober G., Szweda St., 2004. Ocena dokładności wyznaczania obcią̇enia stropnicy i osłony sekcji obudowy zmechanizowanej na podstawie wyników pomiarów dołowych. Zeszyty Naukowe Politechniki Śląskiej, Seria: Górnictwo 260, 439-449.

Medhurst T.P., 2005a. Embracing the future. World Coal.

Medhurst T.P., 2005b. Practical Considerations in Longwall Support Behaviour and Ground Reaction. Coal Operators Conference, University of Wollongong \& the Australasian Institute of Mining and Metallurgy. 49-57.

Medhurst T.P., Brown E.T., 1998. A study of the mechanical behavior of coal for pillar design. Int. J. Rock Mech. Min. Sci. and Geomech. 1087-1105.

Pawlikowski A., 2014. Ocena wplywu czynników konstrukcyjnych i eksploatacyjnych na podporność sekcji obudowy zmechanizowanej. Rozprawa doktorska, Politechnika Śląska, Gliwice.

Rajwa P., 2004. Wplyw konstrukcji stojaka hydraulicznego w ścianowej obudowie zmechanizowanej na utrzymanie stopu. Rozprawa doktorska. Główny Instytut Górnictwa. Katowice.

Sobota P., 2013. Determination of the friction work of a link chain interworking with sprocket drum. Arch. Min. Sci. 58, 3, 805-822, Kraków.

Stoiński K., 2000: Obudowy górnicze w warunkach zagrożenia wstrząami górotworu. Główny Instytut Górnictwa, Katowice.

Szweda St., 2004. Identyfikacja parametrów charakteryzujących obciązenie sekcji obudowy zmechanizowanej spowodowane dynamicznym oddziaływaniem górotworu. Zeszyty Naukowe Politechniki Śląskiej, Seria: Górnictwo 259, Gliwice. 